\title{
Implementasi Sekolah Lapang Iklim dan Dosis Pupuk Terhadap Karakter Kimia Tanah Serta Hasil Jagung
}

\author{
Rifqi Ramadhani ${ }^{1)}$, Khomariah ${ }^{2)}$, Sumani ${ }^{2)}$, Dwi Priyo Ariyanto ${ }^{2)}$
}

\begin{abstract}
Indonesian Agency for Meteorology Climatology and Geophysics Agency (BMKG) stated that the implementation of CFS program can increase the production significantly up to 30\% (BMKG 2016). This research was conducted to know the influence of climate field school (CFS) and fertilizer dosage on soil chemical properties and corn yield. The study was conducted with a nested experimental design with two factors. Factor $A$ has two levels: CFS Program (S1) and nonCFS (S2) and factor B was fertilizer dose. Factor B is nested on factor A as A (B). The fertilizer dose factor consists of 6 levels; T0 (without fertilizer); T1 (100\% organic fertilizer); T2 (75\% organic $+25 \%$ inorganic fertilizer); T3 (50\% organic + 50\% inorganic fertilizer), T4 (25\% organic $+75 \%$ inorganic fertilizer), T5 $(100 \%$ inorganic fertilizer). The results showed that CFS program increased available $\mathrm{P}$, available $\mathrm{K}$ and soil $\mathrm{pH}$, while fertilizer dose $(50 \%$ organic fertilizer $+50 \%$ inorganic fertilizer) on CFS program yielded the highest soil organic matter (4.12\%). CFS and fertilizer dose both did not affect the yield of maize significantly. However, the average yield of maize on CFS land is greater ( 6.50 ton/ha) compared to nonCFS $(5.38$ ton/ha). The treatment with $100 \%$ inorganic fertilizers) on CFS program gives highest yield (8.75 ton/ha).
\end{abstract}

Keywords: Climate Field School, Fertilizer Dose, Soil Chemical Properties

\section{PENDAHULUAN}

Iklim merupakan faktor penting dalam budidaya pertanian. Seiring berjalannya waktu perubahan unsur iklim seperti curah hujan semakin bervariasi setiap tahunnya bahkan sampai pada tingkat yang ekstrim seperti banjir dan kekeringan yang akan berdampak buruk bagi sektor pertanian. Dampak buruk berupa kegagalan panen diperparah karena ketidakmampuan pelaku usaha tani untuk membaca kondisi iklim yang bervariasi. Las (2007) menyatakan peningkatan kejadian iklim ekstrim mengakibatkan kegagalan panen dan kerusakan tanaman yang mempengaruhi produktivitas.

Boer (2009) bahwa semakin majunya sistem pengamatan iklim global dan teknologi perkiraan iklim sangat memungkinkan untuk memprediksi keadaan iklim 2-6 bulan yang akan membantu kegiatan usaha tani,namun pemanfaatan data perkiraan iklim ini masih sangat rendah oleh petani dikarenakan penyebaran informasi terkait data perkiraan iklim masih belum efektif serta metode penyampaian belum efisien.

Kondisi cuaca yang tidak menentu menyebabkan terjadinya dinamika kadar lengas yang akan mempengaruhi hasil tanaman. Kadar lengas juga akan mempengaruhi unsur-unsur kimia dalam tanah yang dibutuhkan tanaman karena kadar lengas juga berfungsi melarutkan unsur kimia agar mudah diserap tanaman. Maka diperlukan pengetahuan mengenai pemantauan cuaca agar petani mampu mengambil keputusan dalam menerapkan praktik budidaya yang efisien.

\footnotetext{
${ }^{1)}$ Mahasiswa S1 Program Studi Agroteknologi, Fakultas Pertanian, Universitas Sebelas Maret

${ }^{2}$ Staf Dosen Program Studi Ilmu Tanah, Fakultas Pertanian,

Universitas Sebelas Maret
}

Author contact: komariah23@gmail.com
Upaya untuk mengatasi keterbatasan petani dalam pemanfaatan data perkiraan cuaca lokal yang dilakukan pemerintah dalam hal ini oleh Badan Meteorologi Klimatologi dan Geofisika (BMKG) menciptakan program Sekolah Lapang Iklim (SLI). Program SLI memfokuskan pembelajaran melalui kegiatan praktek langsung di lapangan tentang pengelolaan agroekosistem dari aspek iklim. Program SLI mengharapkan petani mampu membaca kondisi iklim serta kearifan lokal untuk melaksanakan budidaya spesifik lokasi untuk meminimalisir penurunan produksi akibat fenomena iklim.

BMKG menyatakan bahwa penerapan program SLI pada budidaya mampu meningkatkan hasil tanaman lebih kurang 30\%. Selama penerapan program SLI diberbagai daerah masih belum ada kajian mengenai seberapa besar pengaruh SLI terhadap faktor penentu hasil tanaman dalam hal ini terkait karakteristik kimia tanah yang mendukung pertumbuhan tanaman, serta dosis pupuk yang tepat dalam penerapan program SLI pada pertanaman jagung. Berdasarkan hal tersebut perlu dilakukan peneltian untuk mengakaji Pengaruh Implementasi Sekolah Lapang Iklim dan Dosis Pupuk terhadap Karakter Kimia serta Hasil Jagung Hibrida di Desa Wonosari Kabupaten Karanganyar.

\section{BAHAN DAN METODE}

Penelitian ini dilaksanakan di Desa Wonosari, Kecamatan Gondangrejo Kabupaten Karanganyar. Waktu pelaksanaan penelitian dilakukan selama empat bulan, yaitu pada bulan Juli sampai Oktober 2016 dan analisis kimia tanah di Laboratorium Kimia Tanah Fakultas Pertanian UNS pada bulan September hingga November 2016. Bahan yang digunakan dalam 
penelitian ini antara lain benih jagung hibrida P-35, pupuk organik granul, pupuk urea, pupuk SP36, pupuk $\mathrm{KCl}$, sampel tanah awal dan akhir serta kemikalia untuk analisis kimia tanah. Alat yang digunakan dalam penelitian ini antara lain cangkul, ombrometer, termohigrograf, sangkar cuaca, bor tanah dan lain-lain.

Analisis laboratorium dilakukan dengan menganalisis tanah sampel dari kedua lahan pertanaman jagung. Analisis tanah meliputi analisis tanah awal dan analisis tanah akhir untuk mengetahui pengaruh perlakuan terhadap kondisi tanah. Analisis tanah yang dilakukan yaitu kadar lengas, $\mathrm{pH}$, tekstur, bahan organik (BO), KTK, dan N total tanah, $\mathrm{P}$ tersedia dan $\mathrm{K}$ tersedia tanah.
Penelitian ini menggunakan Rancangan Tersarang (Nested) yang terdiri dari dua faktor Faktor A dua taraf yaitu Sekolah Lapang Iklim (S1) dan Non Sekolah Lapang Iklim (S2) dan faktor B 6 taraf dosis pupuk dengan tiga kali pengulangan. Faktor $B$ tersarang pada faktor $A, A(B)$.

Dosis pupuk mengacu pada KATAM (Kalender Tanam) Badan Penelitian dan Pengembangan Pertanian (2016) mengenai dosis pupuk anorganik anjuran untuk daerah gondangrejo adalah $350 \mathrm{~kg} / \mathrm{ha}$ Urea, $125 \mathrm{~kg} / \mathrm{ha}$ SP 36 dan $100 \mathrm{~kg} / \mathrm{ha} \mathrm{KCL}$ (dosis $100 \%$ anorganik) dan Pupuk organik sebesar 5 ton/ha (dosis $100 \%$ organik). Faktor dosis pupuk terdiri dari 6 taraf:

Tabel 2 Perlakuan dosis pupuk

\begin{tabular}{|c|c|c|c|c|}
\hline \multirow{2}{*}{ Perlakuan } & \multirow{2}{*}{ Pupuk Organik } & \multicolumn{3}{|c|}{ Pupuk Anorganik } \\
\hline & & Urea & SP-36 & $\mathrm{KCl}$ \\
\hline T0 (tanpa pupuk) & 0 & 0 & 0 & 0 \\
\hline T1 (100\% pupuk organik) & 5000 & 0 & 0 & 0 \\
\hline T2 (75\% pupuk organik $+25 \%$ pupuk anorganik) & 3750 & 87,5 & 31,25 & 25 \\
\hline T3 (50\% pupuk organik $+50 \%$ pupuk anorganik) & 2500 & 175 & 62,5 & 50 \\
\hline T4 (25\% pupuk organik $+75 \%$ pupuk anorganik) & 1250 & 262,5 & 93,75 & 75 \\
\hline T5 (100\% pupuk anorganik) & 0 & 350 & 125 & 100 \\
\hline
\end{tabular}

\section{HASIL DAN PEMBAHASAN}

\section{Kondisi umum lingkungan}

Desa Wonosari, Kecamatan Gondangrejo, Kabupaten Karanganyar termasuk daerah memiliki jenis tanah inceptisol. pada ketinggian 267 meter diatas permukaan laut dan terletak pada $7^{\circ} 29^{\prime} 50^{\prime \prime}$ LS dan 11051'26" BT. Selama bulan Juli - Oktober 2016 jumlah curah hujan di Desa Wonosari adalah 974,7 $\mathrm{mm}$. Suhu udara berkisar antara $25-32^{\circ} \mathrm{C}$ dengan kelembaban 68-97\%. Hasil analisis tanah awal pada Tabel 3 menunjukan bahwa lahan SLI dan non SLI memiliki KTK yang tinggi masing-masing sebesar 31,28 $\mathrm{cmol}(+) / \mathrm{kg}$ dan $27,60 \mathrm{cmol}(+) / \mathrm{kg}$ menurut Ryan et al. (2015) KTK pada tanah inceptisol cenderung tinggi. Hal Table 3 Analisis Tanah Awal ini diduga terjadi dikarenakan oleh banyaknya bahan organik yang berperan sebagai koloid tanah merupakan faktor utama dalam penentuan besar kecilnya KTK tanah dan tekstur klei. Lahan SLI dan non SLI memiliki tekstur klei, pH agak asam masingmasing 5,59 dan 5,57. Menurut Purwanto et al. (2014) tingkat kemasaman tanah atau $\mathrm{pH}$ dari tanah inceptisol ini agak masam sampai netral dengan $\mathrm{pH}$ 5,9 - 7,2. Kandungan bahan organik sangat rendah sebesar $0,248 \%$ pada lahan SLI dan $0,175 \%$ pada lahan non SLI. Menurut Prasetyo (2007) Kandungan bahan organik pada tanah inceptisol umumnya tergolong sangat rendah, berkisar antara 0,06\% hingga 4,46\% dan menurun seiring kedalaman tanah. Pada kedua lahan SLI dan non SLI N total tanah tergolong sedang, yaitu sebesar $0,260 \%$ dan $0,237 \%$.

\begin{tabular}{|c|c|c|c|}
\hline Variabel Tanah & SLI & NonSLI & Satuan \\
\hline KTK & $31,28^{* * * *}$ & $27,6^{* \star * *}$ & $\mathrm{Cmol}(+) / \mathrm{kg}$ \\
\hline Tekstur & Klei & Klei & - \\
\hline - Debu & 16,30 & 22,61 & $\%$ \\
\hline - Pasir & 41,88 & 30,95 & $\%$ \\
\hline - Klei & 41,81 & 46,42 & $\%$ \\
\hline $\mathrm{pH}$ & 5,59 (agak masam) & 5,57 (agak masam) & - \\
\hline Bahan Organik & $0,248^{*}$ & $0,175^{\star}$ & $\%$ \\
\hline $\mathrm{N}$ total & $0,260^{* * *}$ & $0,237^{* * *}$ & $\%$ \\
\hline $\mathrm{P}$ tersedia & $5,564^{* *}$ & $5,696^{* *}$ & ppm \\
\hline $\mathrm{K}$ tersedia & $0,003^{*}$ & $0,012^{*}$ & $\mathrm{Cmol}(+) / \mathrm{kg}$ \\
\hline
\end{tabular}

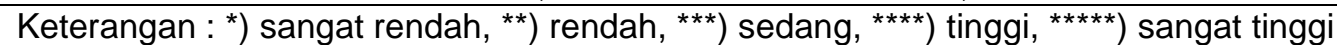

Pengharkatan karakter tanah berdasarkan Balai Penelitian Tanah (200

Analisis $P$ tersedia menunjukan lahan SLI tergolong memiliki unsur $P$ tersedia yang rendah sebesar 5,564 ppm, begitu juga dengan lahan non SLI yang tergolong rendah dengan kandungan $P$ tersedia sebesar 5,696 ppm. $\mathrm{K}$ tersedia tergolong sangat rendah, pada lahan
SLI sebesar $0,003 \mathrm{cmol}(+) / \mathrm{kg}$ dan non SLI sebesar $0,012 \mathrm{cmol}(+) / \mathrm{kg}$. Selanjutnya, dinamika kadar lengas dan curah hujan disajikan pada Gambar 1 dan Gambar 2.Berdasarkan hasil analisis tanah awal, diperoleh hasil yang disajikan dalam Tabel 3 . 


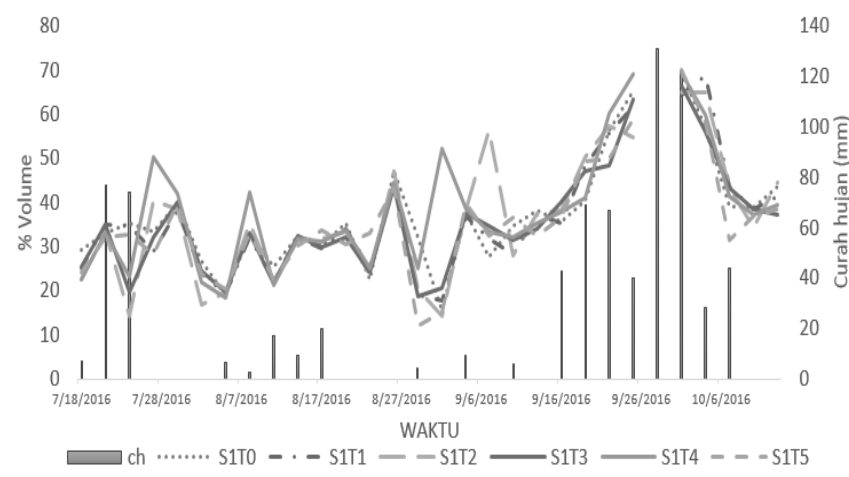

Gambar 1. Grafik Kadar Lengas Tanah dan Curah Hujan Lahan SLI

Gambar 1 dan Gambar 2 menyajikan dinamika lengas tanah yang diamati pada SLI dan non SLI per tiga hari selama masa tanam. Lengas tanah pada lahan SLI cenderung stabil pada awal pengamatan, berkisar antara 14,36\% - 50,28\% (Gambar 1), dimana total curah hujan pada bulan Juli mencapai $254 \mathrm{~mm}$. Penurunan lengas tanah pada implementasi program SLI terendah terjadi selama bulan Agustus hingga 1 September yang diikuti dengan penurunan jumlah curah hujan. Pada bulan Agustus curah hujan cukup rendah sebesar $50 \mathrm{~mm}$ sehingga dalam tindakan evaluasi per dasarian dilakukan penyiraman sebanyak tiga kali untuk meningkatkan kembali lengas tanah. Gambar 1 dan 3 menunjukkan garis yang terputus pada tanggal 28 September 2016, karena lahan tergenang air yang diakibatkan hujan terus menerus ditandai dengan tingginya curah hujan pada bulan September yaitu $364,5 \mathrm{~mm}$ sehingga dilakukan tindakan drainase pada tanggal 29 September 2016 (tabel 1). Tindakan drainase ini membuat lengas tanah berangsur menurun mendekati kapasitas lapang lebih kurang $60 \%$, diiringi dengan penurunan jumlah curah hujan di awal bulan Oktober dan masih dilakukan drainase untuk menjaga lahan tidak tergenang karena jumlah curah hujan yang masih tinggi.

Grafik dinamika lengas tanah pada non SLI pada Gambar 2 menyajikan dinamika lengas tanah yang tidak berbeda jauh dengan Gambar 1. Gambar 2

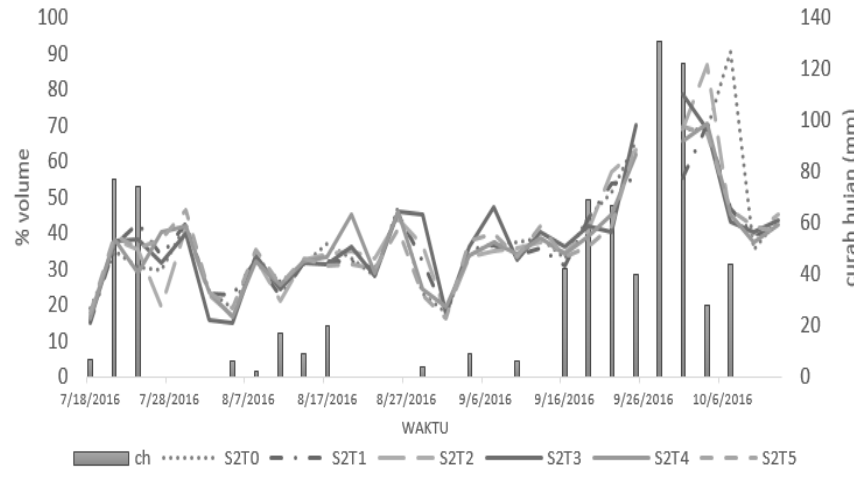

Gambar 2. Grafik Kadar Lengas Tanah dan Curah Hujan Lahan SLI

menunjukkan bahwa lengas tanah terendah terjadi pada tanggal 18 Juli 2016 di lahan non SLI perlakuan (S2T1) sebesar 15,02\% dan tertinggi pada 30 Juli 2016 adalah di perlakuan S2T5 (46,62\%). Total curah hujan pada bulan Juli mencapai $254 \mathrm{~mm}$. Selama bulan Agustus kadar lengas cenderung menurun karena berkurangnya curah hujan sehingga dilakukan penyiraman sesuai kebiasaan petani sebanyak dua kali pada tanggal 23 Agustus 2016 dan 26 Agustus 2016 (Tabel 1). Pada Bulan September 2016 terjadi peningkatan kadar lengas dan curah hujan sebesar $364,5 \mathrm{~mm}$. Pada tanggal 28 September 2016 lahan tergenang karena curah hujan sebelum pengamatan sebesar $202 \mathrm{~mm}$ sehingga tindakan yang diambil adalah drainase pada lahan non SLI (Tabel 1). Akhir masa tanam di awal bulan Oktober grafik masih menunjukkan kadar lengas yang tinggi (diatas 60\%), hal ini karena curah hujan yang masih tinggi dan tindakan drainase yang hanya satu kali. Tindakan yang diambil mengikuti kebiasaan petani setempat yang memilih tidak melakukan drainase yang intensif karena tanaman jagung dirasa sudah cukup kuat terhadap genangan.

\section{Evaluasi Program SLI}

Hasil Evaluasi program yang menerapkan program sekolah lapang iklim dan non sekolah lapang iklim terhadap variabel pengamatan disajikan pada Tabel 3.

Tabel 4 Evaluasi Hasil Uji F Program Program SLI terhadap Variabel Pengamatan

\begin{tabular}{|c|c|c|c|}
\hline \multirow{2}{*}{ Parameter } & \multicolumn{2}{|c|}{ Rataan } & \multirow{2}{*}{ P Value } \\
\hline & SLI & Non SLI & \\
\hline N Total Tanah & $0,284 \%$ & $0,282 \%$ & 0,916 (ns) \\
\hline P Tersedia Tanah & $6,336 \mathrm{ppm}$ & $5,835 \mathrm{ppm}$ & $0,044^{*}$ \\
\hline K Tersedia Tanah & $0,008 \mathrm{cmol}(+) / \mathrm{kg}$ & $0,006 \mathrm{cmol}(+) / \mathrm{kg}$ & $0,010^{*}$ \\
\hline Bahan Organik & $3,53 \%$ & $3,43 \%$ & $0,406(n s)$ \\
\hline KTK & $33,35 \mathrm{cmol}(+) / \mathrm{kg}$ & $32,52 \mathrm{cmol}(+) / \mathrm{kg}$ & 0,690 (ns) \\
\hline $\mathrm{pH} \mathrm{H}_{2} \mathrm{O}$ & 6,64 & 6,24 & $0,009^{* *}$ \\
\hline Produksi Jagung & 6,495 ton/ha & 5,382 ton/ha & $0,124(\mathrm{~ns})$ \\
\hline
\end{tabular}

Keterangan : * : berpengaruh nyata pada $\alpha=0,05$

${ }^{* *}$ : sangat berpengaruh nyata pada $\alpha=0,05$

Perlakuan Sekolah Lapang (SLI dan non SLI) tidak berpengaruh nyata terhadap $N$ total tanah $(p=0,916)$, Bahan Organik Tanah $(p=0,406)$, Kapasitas Tukar

Kation (KTK) $(p=0,690)$ dan Produksi Jagung $(p-0,124)$. Hasil pada Tabel 4 menunjukan perlakuan Implementasi program SLI dan non SLI berpengaruh 
nyata terhadap $P$ tersedia $(p=0,044)$ dengan rataan $P$ tersedia pada SLI sebesar 6,336 ppm dan pada non SLI rataan $\mathrm{P}$ tersedia sebesar 5,835 ppm, keduanya tergolong sangat rendah. Ketersedian $\mathrm{P}$ pada program SLI lebih tinggi dibandingkan non SLI karena adanya perbedaan tindakan pemeliharaan berdasarkan hasil evaluasi (SLI) dan kebiasaan petani (non SLI) (tabel 1). Perlakuan SLI mendapatkan tindakan penyiraman lebih banyak dibanding non SLI. Menurut Hartati et al. (2014) dalam penelitiannya menyatakan bahwa penyiraman akan membuat $\mathrm{P}$ dalam bentuk $\mathrm{H}_{2} \mathrm{PO}^{-}$maupun $\mathrm{HPO}_{4}{ }^{2-}$ lebih mudah larut sehingga tersedia bagi tanaman.

Tabel 4 menunjukkan bahwa kandungan $\mathrm{K}$ tersedia tanah $(p=0,010)$ berpengaruh nyata pada kedua lahan (SLI dan non SLI) dengan rataan $\mathrm{K}$ tersedia pada SLI dan non SLI masing-masing sebesar 0,008 dan $0,006 \mathrm{cmol}(+) / \mathrm{kg}$. Rata-rata peningkatan $\mathrm{K}$ tersedia tanah yang lebih tinggi adalah pada program SLI. Berdasarkan tindakan pemeliharaan yang dapat dilihat dari (tabel 1) penyiraman perlakuan program SLI lebih banyak dibanding perlakuan Non SLI, yang membuat kadar lengas tanah lebih tersedia dalam tanah. Ion-ion $\mathrm{K}$ akan terjerap diantara satuan-satuan struktur lempung yang mengerut pada waktu tanah mengering. Menurut Tisdale dan Nelson (1975) kadar lengas yang terlalu tinggi dapat menyebabkan penurunan ketersedian K akibat fiksasi K. Penelitian Suwarto (2003) menyatakan bahwa ketersedian K dalam tanah ditentukan oleh kadar lengas tanah, terutama berkaitan dengan fiksasi mineral lempung tertentu. Berdasarkan Tabel 3 bahwa sekolah lapang (SLI dan non SLI) sangat berpengaruh nyata terhadap $\mathrm{pH}$ tanah $(p=0,009)$. Nilai rataan pada SLI sebesar 6,64 dan non SLI sebesar 6,24. Pada (tabel 1) terdapat perbedaan pemeliharaan, diantaranya intensitas penyiraman, pengendalian gulma, dan drainase. Pada non SLI pengendalian gulma dilakukan dengan cara penyemprotan herbisida. Penggunaan herbisida dapat menyebabkan penurunan $\mathrm{pH}$. Menurut Muzaiyanah dan Harsono (2015) pemberian herbisida dapat menurunkan $\mathrm{pH}$ tanah yang mengakibatkan terjadinya penurunan kandungan $\mathrm{P}$ tersedia di dalam tanah. Selain pemberian herbisida, faktor yang mempengaruhi $\mathrm{pH}$ tanah adalah penggenangan. Pada Gambar 2 lengas tanah pada akhir pengamatan selalu berada diatas $60 \%$ mengakibatkan penurunan pada $\mathrm{pH}$ tanah.

\section{Pengaruh Dosis Pupuk terhadap Karakter Kimia Tanah dan Hasil Jagung}

Hasil analisis laboratorium pengaruh imbangan dosis pupuk terhadap sifat kimia disajikan sebagai berikut :

Tabel 5 Pengaruh Imbangan dosis pupuk terhadap karakteristik kimia tanah

\begin{tabular}{lcccccc}
\hline Perlakuan & $\mathrm{pH}$ & $\mathrm{N}$ Total $(\%)$ & $\begin{array}{c}\text { P Tersedia } \\
(\mathrm{ppm})\end{array}$ & $\begin{array}{c}\text { K Tersedia } \\
(\mathrm{ppm})\end{array}$ & $\begin{array}{c}\text { KTK } \\
(\mathrm{me} / 100 \mathrm{~g})\end{array}$ & $\begin{array}{c}\text { Bahan Organik } \\
(\%)\end{array}$ \\
\hline S1T0 & $6,48 \pm 0,49$ & $0,26 \pm 0,04$ & $6,18 \pm 0,73$ & $0,01 \pm 0,00$ & $31,49 \pm 4,25$ & $3,68 \mathrm{a} \pm 0,46$ \\
S1T1 & $7,16 \pm 0,38$ & $0,27 \pm 0,04$ & $6,04 \pm 0,48$ & $0,01 \pm 0,00$ & $33,47 \pm 1,32$ & $3,23 \mathrm{a} \pm 0,38$ \\
S1T2 & $6,42 \pm 0,01$ & $0,27 \pm 0,03$ & $6,56 \pm 1,03$ & $0,01 \pm 0,00$ & $32,59 \pm 3,92$ & $3,32 \mathrm{a} \pm 0,09$ \\
S1T3 & $6,96 \pm 0,32$ & $0,29 \pm 0,03$ & $6,00 \pm 1,01$ & $0,01 \pm 0,00$ & $31,87 \pm 2,80$ & $4,12 \mathrm{~b} \pm 0,09$ \\
S1T4 & $6,23 \pm 0,13$ & $0,30 \pm 0,03$ & $5,61 \pm 0,26$ & $0,01 \pm 0,00$ & $35,85 \pm 2,83$ & $3,26 \mathrm{a} \pm 0,13$ \\
S1T5 & $6,61 \pm 0,05$ & $0,29 \pm 0,01$ & $7,61 \pm 0,96$ & $0,01 \pm 0,00$ & $34,83 \pm 4,01$ & $3,56 \mathrm{a} \pm 0,10$ \\
S2T0 & $5,85 \pm 0,70$ & $0,24 \pm 0,03$ & $5,56 \pm 0,14$ & $0,01 \pm 0,00$ & $25,20 \pm 4,89$ & $3,39 \pm 0,37$ \\
S2T1 & $6,48 \pm 0,44$ & $0,24 \pm 0,05$ & $5,81 \pm 0,52$ & $0,01 \pm 0,00$ & $34,00 \pm 5,88$ & $3,40 \pm 0,61$ \\
S2T2 & $6,11 \pm 0,32$ & $0,30 \pm 0,02$ & $6,22 \pm 0,64$ & $0,01 \pm 0,00$ & $27,41 \pm 2,65$ & $3,96 \pm 0,44$ \\
S2T3 & $6,33 \pm 0,31$ & $0,31 \pm 0,13$ & $5,95 \pm 0,54$ & $0,01 \pm 0,00$ & $36,13 \pm 8,25$ & $3,54 \pm 0,22$ \\
S2T4 & $6,59 \pm 0,38$ & $0,28 \pm 0,02$ & $5,97 \pm 0,90$ & $0,01 \pm 0,00$ & $32,85 \pm 5,09$ & $3,26 \pm 0,13$ \\
S2T5 & $6,07 \pm 0,13$ & $0,36 \pm 0,06$ & $5,47 \pm 0,36$ & $0,01 \pm 0,00$ & $39,55 \pm 4,69$ & $3,05 \pm 0,24$ \\
\hline
\end{tabular}

Catatan: angka dalam baris yang diikuti huruf sama atau tanpa diikuti huruf tidak berbeda nyata pada ANOVA 0,05

\section{N Total Tanah}

Hasil perlakuan dosis pupuk pada lahan SLI maupun lahan Non SLI tidak berpengaruh nyata terhadap $\mathrm{N}$ total tanah $(\mathrm{p}=0,808)$. Menurut Putra et al. (2015) aplikasi urea tidak berpengaruh nyata terhadap $\mathrm{N}$ total tanah karena unsur hara $\mathrm{N}$ pada pupuk urea cepat tersedia bagi tanaman tetapi cepat juga hilang karena pencucian, penguapan dan unsur hara $\mathrm{N}$ bersifat sangat mobil. Tong et. al (2009) pemeberian pupuk $\mathrm{N}$ tidak memberikan efek yang nyata terhadap penambahan $\mathrm{N}$ total tanah.

\section{P Tersedia Tanah}

Hasil perlakuan dosis pupuk pada lahan SLI maupun lahan Non SLI tidak berpengaruh nyata terhadap $P$ tersedia tanah $(p=0,144)$. Meskipun tidak berpengaruh nyata kandungan $P$ tersedia tanah tertinggi ditunjukan pada dosis pupuk S1T5 (0\% pupuk organik + 100 pupuk anorganik) sebesar 7,608 ppm. Hal ini disebabkan karena penambahan pupuk anorganik mampu menyediakan $P$ yang siap dimanfaatkan tanaman lebih cepat. Gudzic et al. (2015) menyatakan bahwa penambahan pupuk $\mathrm{P}$ mampu meningkatkan $P$ tersedia tanah. Hal ini diperkuat dengan pernyataan EI Seoud dan Megeed (2011) dengan penambahan batuan phospat dan pupuk $P$ akan meningkatkan $\mathrm{P}$ tersedia yang dapat diserap tanaman.

\section{K Tersedia Tanah}

Unsur $\mathrm{K}$ merupakan unsur penting dalam proses metabolisme sel pada tanaman (Akande et.al 2008) sehingga ketersediaannya perlu di perhatikan salah satu caranya adalah penambahan pupuk $\mathrm{KCl}$. Menurut Hasil perlakuan dosis pupuk pada lahan SLI maupun lahan Non SLI tidak berpengaruh nyata terhadap K 
tersedia tanah $(p=0,410)$. Zhao et al. (2014) bahwa pemberian pupuk $\mathrm{K}$ tidak signifikan meningkatkan $\mathrm{K}$ tersedia tanah. Sejumlah pupuk K yang ditambahkan ke dalam tanah akan mengalami fiksasi oleh mineral lempung tertentu yang tidak dapat dimanfaatkan oleh tanaman. Seng dan Huang (2002) menyatakan bahwa penurunan $\mathrm{K}$ tersedia dapat disebabkan oleh diserap tanaman, air limpasan, pencucian dan erosi.

\section{KTK tanah}

Hasil uji F perlakuan dosis pupuk pada lahan SLI maupun lahan Non SLI tidak berpengaruh nyata terhadap KTK tanah $(p=0,295)$. Berdasarkan hasil uji $F$ dosis pupuk dosis pupuk tidak berpengaruh nyata (ns) terhadap KTK $(p=0,295)$. Meskipun demikian, hasil analisis laboratorium menunjukkan bahwa KTK pada

Gambar 3. Pengaruh Dosis Pupuk Terhadap

Hasil Jagung Lahan SLI

seluruh perlakuan tergolong tinggi.

\section{pH tanah}

Hasil uji F perlakuan dosis pupuk pada lahan SLI maupun lahan Non SLI tidak berpengaruh nyata terhadap $\mathrm{pH}$ tanah $(\mathrm{p}=0,144)$. Penelitian Cyio (2008) menyatakan bahawa penurunan $\mathrm{pH}$ disebabkan penggenangan dan persentase bahan organik. Meskipun demikian perlakuan sistem budidaya SLI pH tertinggi ditunjukan pada perlakuan S1T1 sebesar 7,16 tergolong netral dan terendah adalah S1T4 dengan $\mathrm{pH}$ sebesar 6,23 tergolong agak masam (Tabel 5). Peningkatan $\mathrm{pH}$ ini dirangsang oleh mikroorganisme yang ada di dalam bahan organik Jayalath et. al (2015). Menurut Havlin et al. (2015) bahwa pH tanah optimum untuk pertumbuhan jagung berkisar 5,5- 7,0.

\section{Bahan Organik}

Hasil pada (Tabel 5) menunjukkan bahwa dosis pupuk berpengaruh nyata terhadap bahan organik tanah $(p=0,032)$ di SLI. hasil uji $F$ rerata bahan organik S1T0,S1T1, S1T2,S1T4,S1T5 berbeda nyata terhadap S1T3 (Pupuk organik 50\% + pupuk anorganik 50\%) memiliki bahan organik sebesar 4,12 \% tergolong tinggi. Nilai tertinggi pada perlakuan dosis S2T2 ( $75 \%$ pupuk organik $+25 \%$ pupuk anorganik) atau 3750 $\mathrm{kg} / \mathrm{ha}$ organik + 87,5 kg/ha Urea + 31,25 kg/ha SP36 + $25 \mathrm{~kg} / \mathrm{ha} \mathrm{KCL}$ sebesar 3,96 \% tergolong tinggi Menurut (Carey et al. 2009) semakin tinggi bahan organik, maka semakin bertambah sumber muatan negatif yang menyebabkan KTK tanah meningkat. Penggunaan pupuk organik memberikan efek yang lebih besar terhadap ketersedian bahan organik dalam tanah ketimbang pupuk anorganik (Herensia et. al 2011)

\section{Hasil Jagung}

Hasil uji F perlakuan dosis pupuk pada lahan SLI maupun lahan Non SLI tidak berpengaruh nyata terhadap hasil jagung $(p=0,063)$. Seluruh perlakuan dosis pupuk pada non SLI menunjukkan hasil yang tidak berpengaruh nyata. Hasil tertinggi S1T5 sistem SLI (0 pupuk organik + 100\% pupuk anorganik) sebesar
8,75 ton/ha. Hasil jagung terendah terdapat perlakuan S1T0 (tanpa pupuk) 3,22 ton/ha diikuti perlakuan S1T1 4,49 ton/ha, S1T2 6,62 ton/ha S1T3 7,28 ton/ha dan S1T4 8,61 ton/ha. Soro et al. (2015), menyatakan bahwa penambahan pupuk anorganik dapat memenuhi kebutuhan hara makro dan mikro serta mencegah kekahatan hara.

\section{KESIMPULAN}

1. Implementasi program Sekolah Lapang Iklim meningkatkan $\mathrm{P}$ tersedia, $\mathrm{K}$ tersedia dan $\mathrm{pH}$ tanah, sedangkan dosis pupuk (Pupuk organik 50\% + pupuk anorganik 50\%) pada program SLI menghasilkan bahan organik tanah tertinggi $(4,12 \%)$.

2. Implemtasi program Sekolah Lapang Iklim dan dosis pupuk keduanya tidak mempengaruhi hasil jagung. Namun rata-rata hasil jagung pada lahan program SLI lebih besar $(6,50$ ton/ha) dibandingkan dengan program non SLI (5,38 ton/ha). ). Perlakuan S1T5 (0 pupuk organik $+100 \%$ pupuk anorganik) pada program SLI memberikan hasil tertinggi $(8,75$ ton/ha).

\section{UCAPAN TERIMAKASIH KEPADA :}

BMKG yang telah mendukung pelaksanaan program Sekolah Lapang Iklim

DIPA UNS yang telah mendungkung anggaran

\section{DAFTAR PUSTAKA}

[BMKG] (Indonesian Agency for Meteorology Climatology and Geophysics Agency). 2016. SLI tahap III Jambi. http://www.bmkg.go.id/berita/?p=slitahap-iii-jambi\&lang=ID. Diakses pada 30 Juli 2016 pukul 09.00 WIB.

Akande MO, Adediran JA, Oluwatoyinbo FI, Makinde EA Adetunji MT. 2008. Suitability of poultry manure amendedSokoto rock phosphate on growth, nutrient uptake and yield ofchilli pepper (Capsicum fruitscens L). Niger. J Soil Sci. 18(1):167-174.

[BPPP] Badan Penelitian dan Pengembangan Pertanian. 2016. Katam terpadu moderen. http://katam.litbang.pertanian.go.id/main.aspx. Diakses pada 30 Juli 2016 pukul 08.50 WIB.

[BPT] Balai Penelitian Tanah. 2005. Petunjuk teknis analisis kimia tanah, tanaman, air, dan pupuk. Bogor : Balai Penelitian Tanah.

Boer R 2009. Sekolah lapangan iklim antisipasi resiko perubahan iklim. Kepala Laboratorium Klimatologi, Departemen Geomet-FMIPA IPB dan Ketua Umum Perhimpunan Meteorologi Pertanian Indonesia. Institut Pertanian Bogor. Bogor

Carey PL, Benge JR, Haynes RJ. 2009. Comparison of soilq and nutrient budgets between organic and conventional kiwifruit orchards. Agricultural,Ecosystems and Environment 132(1): 715.

Cyio MB. 2008. Efektivitas bahan organik dan tinggi genangan terhadap perubahan $\mathrm{Eh}, \mathrm{Ph}$, dan status 
Fe, P, Al terlarut pada Tanah Ultisol. J. Agroland 15(4):257- 263.

El Seoud IIA, Megeed AA. 2011. Impact of rock materials and biofertilizations on $\mathrm{P}$ and $\mathrm{K}$ availability for maize (zea maize) under calcareoussoil conditions. Saudi Journal of Biological Sciences. 2012. 19(1):55-63

Gudzic N, Aksic M, Knezevic J, Gudzic S. 2015. Changes in fertility of vertisol and in the content of available forms of fe, $\mathrm{mn}$, cu and zn after thirty years of using phosphate fertilizers. Asian $\mathrm{J}$ Argriculture of Food Sciences. 3(5) : 1-6. ISSN: 2321-1571

Hartati S, Sumani, Hendrata HEA. 2014. Pengaruh imbangan pupuk organik dan anorganik terhadap serapan $\mathrm{p}$ dan hasil tanaman padi sawah pada dua program di lahan sawah sukoharjo. Jurnal IImu IImu Pertanian 29(1) 2014.

Havlin JL, Beaton JD, Tisdale SL. 2015. Soil fertility and fertilizers. An introduction to nutrient management. Seventh edition. J Pear. 12(5) 112-172.

Herencia JF, Garsia PA, Maqueda C. 2011. Long term effect of organic and mineral fertilization on soil physical properties under greenhouse and outdoor management practices. Pedosphere 21(4): 443-453.

Jayalath N, Mosley LM, Fitzpatrick RW, Marschner. 2016. Addition of organic matter influences ph changes in reduced and oxidised acid sulfate soils. Geoderma. 62(2016): 125-132

Las IA, Pramudia, Runtunuwu E. 2011. Antisipasi perubahan iklim dalam mengamankan produksi beras nasional. JPengembangan Inovasi Pertanian 4(1): 76-86.

Muzaiyanah S, Harsono A. 2015. Pengaruh penggunaan herbisida pratumbuh dan pascatumbuh terhadap pertumbuhan gulma dan tanaman kedelai. Prosiding seminar nasional hasil penelitian tanaman aneka kacang dan umbi. Balai Penelitian Tanaman Aneka Kacang dan Umbi.

Prasetyo BH. 2007. Perbedaan sifat-sifat tanah vertisol dari berbagai bahan induk. J IImu Pertanian Indonesia. 9(1) : 20-31.
Purwanto, Hartati S, Istiqomah S 2014. Pengaruh kualitas dan dosis seresah terhadap potensial nitrifikasi tanah dan hasil jagung manis. J IImu Tanah dan Agroteknologi. 11(1) 2014.

Putra AD,Damanik MMB, Hanum H. 2015. Aplikasi pupuk urea dan pupuk kandang kambing untuk meningkatkan n-total pada tanah inceptisol kwala bekala dan kaitannya terhadap pertumbuhan tanaman jagung (Zea mays L.). J Online Agroteknologi 3(1): 128-135. ISSN No. 2337- 6597.

Ryan A, Abdul R Gantar S. Evaluasi sifat kimia tanah inceptisol pada kebun inti tanaman gambir (Uncaria gambir Roxb.) di Kecamatan Salak Kabupaten Pakpak Bharat. J Online Agroteknologi. 3(4): 13291334. ISSN No. 2337-6597.

Sheng XF, Huang W Y. 2002. Mechanism of potassium release from feldspar affected by the strain nbt of silicate bacterium. J Acta Pedol. Sin. 39: 863-871.

Suwarto. 2003. Pengaruh lengas tanah terhadap serapan $\mathrm{k}$ ketersediaannya dalam tanah vertisol. J Sains Tanah 3(1).

Soro D, Koutoua A, Ferdinand GBZ. 2015. Impact of organic fertilization on maize (Zea mays I.) Production in a ferralitic soil of centre-west côte d'ivoire. $J$ of Experimental Biology and Agricultural Science 3(6): 556-565. DOI: http://dx.doi.org/10.18006/2015. 3(6).556.565.

Tisdale SL, Nelson WL. 1975.soil fertility and fertilizer. Third ed. Mac Million Pub. Newyork.

Tong $\mathrm{C}$, Xiao $\mathrm{H}$, Tang $\mathrm{G}$, Wang $\mathrm{H}$, Huang $\mathrm{T}$, Xia $\mathrm{H}$, Keith SJ, Li Y, Liu S, Wu J. 2009. Long-term fertilizer effects on organic carbon and total nitrogen and coupling relationships of $c$ and $n$ in paddy soils in subtropical china. Soil and Tillage Research 106(1): 8-14.

Zhao S Zhao S, Hea P, Qiu S, L, Liu M, Jin J,Johnston AM. 2014. Long-term effects of potassium fertilization and straw return on soil potassium levels and crop yields in north-central china. J field crops research 169 (2014) 116-122. 2014. Long-term effects of potassium fertilization and straw return on soil potassium levels and cropields in north-central china. J Field Crops Research 169(1): 116-122. 